\title{
ONE-DIMENSIONAL ELASTO-PLASTIC MATERIAL MODEL WITH DAMAGE FOR A QUICK IDENTIFICATION OF THE MATERIAL PROPERTIES
}

\author{
ENODIMENZIJSKI MODEL ELASTOPLASTIČNEGA MATERIALA \\ S POŠKODBO ZA HITRO UGOTOVITEV LASTNOSTI MATERIALA
}

\author{
Tomáš Kroupa, Hana Srbová, Jan Klesa \\ University of West Bohemia, NTIS - New Technologies for the Information Society, Univerzitní 22, 306 14, Plzeň, Czech Republic \\ kroupa@kme.zcu.cz
}

Prejem rokopisa - received: 2015-07-01; sprejem za objavo - accepted for publication: 2016-02-10

doi: $10.17222 / \mathrm{mit} .2015 .173$

\begin{abstract}
Material parameters for elastic, plastic and damage behavior of low-molecular-weight epoxy resin CHS-EPOXY 520 hardened with CHS-P 11 are identified in the paper. Uniaxial cyclic static tests were performed on specimens in line with the ASTM standard D638 - 10 using a Zwick Roell/Z050 test machine with a BTC-Exaclbi.001 clip-on biaxial extensometer. Poisson's ratio and tensile strength were calculated directly from the test results. Other parameters were identified using a combination of a one-dimensional material model, which assumes the infinitesimal strain theory and takes into account elastic, plastic and damage behavior and the optimization method. The model is coded in Python and the values of the material parameters are identified using the optiSLang optimization software. The optimization process uses simple design improvement and gradient-based algorithms with the goal to minimize the difference between the force-elongation curves recorded during the tests and those calculated with the proposed model.

Keywords: epoxy, identification, optimization, elasticity, plasticity, damage
\end{abstract}

V članku so opredeljeni parametri epoksi smole z majhno molekulsko maso CHS-EPOXY 520, utrjeno z CHS-p 11, pri elastičnem, plastičnem obnašanju in pri poškodbi. Enoosni statični ciklični preizkusi so bili izvedeni na vzorcih, ki ustrezajo ASTM standardu D638-10, z uporabo Zwick Roell/Z050 preizkusnega stroja z nameščenim dvoosnim ekstenziometrom BTC-Exaclbi.001. Poissonov količnik in natezna trdnost sta bili izračunani neposredno iz rezultatov preizkusov. Drugi parametri so ugotovljeni s kombinacijo enodimenzijskega modela materiala, ki predpostavlja infinitezimalno teorijo napetosti in ki upošteva obnašanje $\mathrm{v}$ elastičnem, plastičnem in ob poškodbi ter metodo optimizacije. Model je kodiran v Pythonu in vrednosti parametrov materiala so ugotovljene z uporabo optiSLang programske opreme za optimizacijo. Proces optimizacije uporablja enostavno izboljšanje oblike in algoritme, ki temeljijo na gradientu, s ciljem po zmanjšanju razlike med krivuljo sila raztezek zabeležene med preizkusom in izračunane $\mathrm{z}$ uporabo predlaganega modela.

Ključne besede: epoksi, identifikacija, optimizacija, elastičnost, plastičnost, poškodba

\section{INTRODUCTION}

A model simulating one-dimensional pure tensile, compressive or shear tests is proposed. This approach is able to predict a one-dimensional response of materials with elastic, plastic and damage behavior. The model is based on the idea to reduce the computational time necessary to identify characteristic parameters of the tested material. The presented model is not necessarily, or primarily, meant to be used for the final identification of material parameters; it can only be used for investigating the starting values or boundaries of the parameters in the subsequent identifications performed using, e.g., a finite-element model ${ }^{1,2}$ or other models. ${ }^{3}$ The model is written in free-licensed programing language Python using only widely used and common modules numpy, matplotlib, os and pickle. Pre-processing of the experimental results for the further identification process is also performed in Python. The paper presents results for pure epoxy resin; nevertheless, the model is not limited to such type of material.

\section{SPECIMENS AND THE EXPERIMENT}

Nine specimens shaped according to ASTM standard D638-10 (Figure 1) were cut from a rectangular plate with dimensions of approx. $140 \mathrm{~mm} \times 250 \mathrm{~mm}$. The specimens were made of low-molecular-weight epoxy resin CHS-EPOXY 520 hardened with CHS-P 11. The

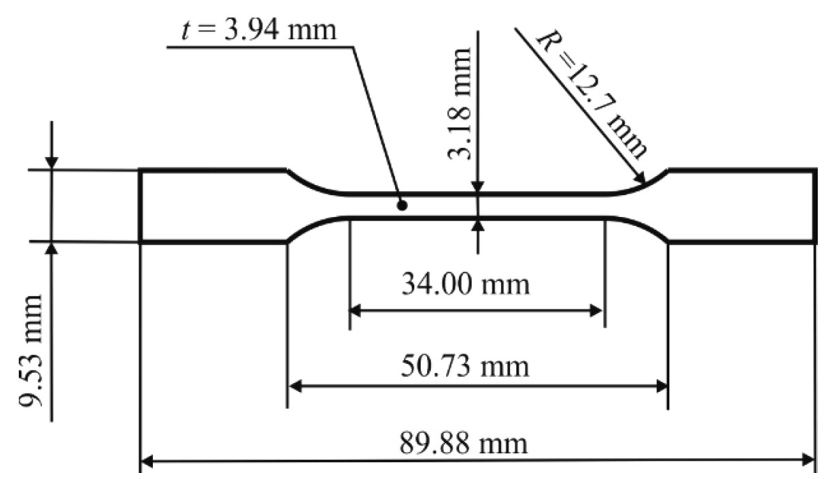

Figure 1: Dimensions of the specimens

Slika 1: Dimenzije vzorcev 


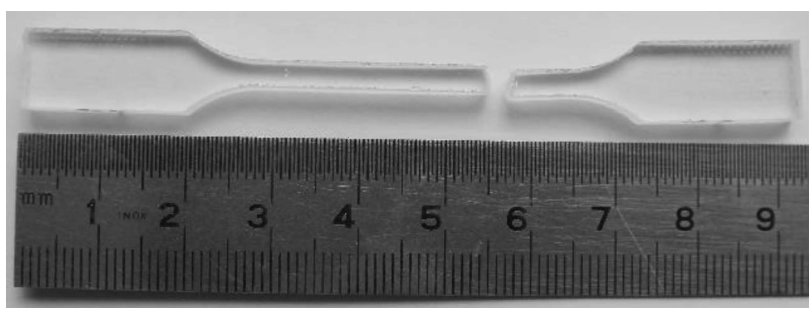

Figure 2: Cracked specimen

Slika 2: Prelomljen vzorec

air from the mixture was removed with a vacuum pump and the resin was then cured at atmospheric pressure, which increased the quality of the epoxy resin by reducing the number and volume of bubbles.

A ZWICK ROELL/Z050 test machine with a BTC-EXACLBI.001 clip-on biaxial extensometer was used for the experimental tests.

The specimens were subjected to cyclic tensile tests. During each cycle, unloading was started every time the elongation between the extensometer arms (the gage area) exceeded a multiple of $\Delta l=0.02 \mathrm{~mm}$. During the corresponding cycle, loading started when the tensile force decreased below the multiple of $30 \%$ of the force at the start of the unloading. All the tests were performed at room temperature of $22{ }^{\circ} \mathrm{C}$. Figure 2 shows a typically cracked specimen with a rupture.

\section{MATERIAL MODEL}

The free-energy-function method was used for the formulation of the model. ${ }^{4,5}$ In this paper, the free-energy function $\psi$ is proposed in the form of the sum of elastic, plastic and damage parts:

$$
\psi=\frac{1}{\rho}\left[\frac{1}{2} E(1-D)\left(\varepsilon^{E}\right)^{2}+\int_{0}^{\bar{\varepsilon}^{\mathrm{P}}} \mathrm{P}\left(\bar{\varepsilon}^{\mathrm{P}}\right) \mathrm{d} \bar{\varepsilon}^{\mathrm{P}}+\int_{0}^{\beta} \mathrm{B}(\beta) \mathrm{d} b\right]
$$

where $\rho$ is the density of the material; $E$ is Young's modulus; $D$ is the damage factor; $\varepsilon^{\mathrm{E}}$ is the elastic strain; $\bar{\varepsilon}^{\mathrm{P}}$ is the equivalent plastic strain; $R$ is the hardeningassociated quantity; $\beta$ is the damage variable; and $B$ is the damage-associated quantity. Generalized forces are described in more detail below. The stress is calculated in Equation (2) as:

$$
\sigma=\rho \frac{\partial \psi}{\partial \varepsilon^{\mathrm{E}}}=E(1-D) \varepsilon^{\mathrm{E}}
$$

where stress $\sigma$ is considered as the nominal stress acting in the whole area of the cross-section of a specimen. Stress $\rho_{\mathrm{D}}$ is the stress acting in the undamaged area of the cross-section of a specimen: ${ }^{4}$

$$
\sigma_{\mathrm{D}}=\frac{\sigma}{(1-D)}=\frac{\sigma}{(1-D)} \frac{\partial \psi}{\partial \varepsilon^{\mathrm{E}}}=E \varepsilon^{\mathrm{E}}
$$

The damage-associated energy, in this case identically equal to the strain energy density of the undamaged material, is

$$
Y=-\rho \frac{\partial \psi}{\partial D}=\frac{1}{2} E\left(\varepsilon^{\mathrm{E}}\right)^{2}
$$

The hardening-associated quantity, which defines the plastic material behavior, is:

$$
R\left(\bar{\varepsilon}^{\mathrm{P}}\right)=\rho \frac{\partial \psi}{\partial \bar{\varepsilon}^{\mathrm{P}}}
$$

And the damage-associated quantity, which defines the damage material behavior, is:

$$
B(\beta)=\rho \frac{\partial \psi}{\partial \beta}
$$

The model is considered as a nonlinear material and the infinitesimal-strain theory is used in Equation (7):

$$
\varepsilon=\frac{\Delta l}{l}
$$

where $\varepsilon$ is the total strain; $\Delta l$ is the elongation of the gage area and $l$ is the original length of the gage area. The elasto-plastic decomposition of the axial strain $\varepsilon$ is also considered:6,7

$$
\varepsilon=\varepsilon^{\mathrm{E}}+\varepsilon^{\mathrm{P}}
$$

where $\varepsilon^{\mathrm{P}}$ is the plastic strain. The function of plasticity decides whether the plastic flow will be present. It is proposed in the following form:

$$
F^{\mathrm{P}}=\sigma_{\mathrm{r}}-\sigma^{\mathrm{y}}=\sigma_{\mathrm{r}}-\left(R_{0}+R\left(\bar{\varepsilon}^{\mathrm{P}}\right)\right) \leq 0
$$

where $\sigma_{\mathrm{r}}=\left|\sigma_{\mathrm{D}}\right|$, which implies the assumption that the plastic flow is present only in the undamaged part of the cross-section and that the plastic flow will occur in tension as well as in compression; $\sigma^{y}$ is the yield stress and $R_{0}$ is the initial yield stress. The function of damage is proposed in the following form:

$$
F^{\mathrm{D}}=Y_{\mathrm{r}}-\left(B_{0}+B(\beta)\right) \leq 0
$$

where $Y_{\mathrm{r}} \equiv Y$, therefore, as in the case of plasticity, no distinction between the tensile and compressive damage is considered; $B_{0}$ is the energy necessary for the damage initiation.

Rates of quantities are expressed below. Time derivatives (".") are replaced by time step changes (" $\Delta "$ ) because all the analyses were performed as quasi-static. The change in the plastic strain $\Delta \varepsilon^{\mathrm{P}}$ is:

$$
\Delta \varepsilon^{\mathrm{P}}=\Delta \lambda^{\mathrm{P}} \frac{\partial F^{\mathrm{P}}}{\partial \sigma}=\Delta \lambda^{\mathrm{P}} \operatorname{sign}(\sigma)
$$

where $\Delta \lambda^{\mathrm{P}}$ is the plastic multiplier. The change in the equivalent plastic strain $\Delta \bar{\varepsilon}^{\mathrm{P}}$ is:

$$
\Delta \bar{\varepsilon}^{\mathrm{P}}=-\Delta \lambda^{\mathrm{P}} \frac{\partial F^{\mathrm{P}}}{\partial R}=\Delta \lambda^{\mathrm{P}}
$$

The change in the damage factor $\Delta D$ is:

$$
\Delta D=-\Delta \lambda^{\mathrm{D}} \frac{\partial F^{\mathrm{D}}}{\partial Y}=\Delta \lambda^{\mathrm{D}}
$$

where $\Delta \lambda^{\mathrm{D}}$ is the damage multiplier. The change in the damage variable is: 


$$
\Delta \beta=-\Delta \lambda^{\mathrm{D}} \frac{\partial F^{\mathrm{D}}}{\partial Y}=\Delta \lambda^{\mathrm{D}}
$$

If inequalities (9) and (10) are fulfilled, the calculation of responses is simple. Otherwise, the changes of the unknown variables $\left(\Delta \varepsilon^{\mathrm{P}}, \Delta \bar{\varepsilon}^{P}, \Delta D, \Delta \beta, \Delta \lambda^{\mathrm{P}}, \Delta \lambda^{\mathrm{D}}\right)$ must be calculated. The following section shows the solution of this problem in the presented model.

\section{CALCULATION OF RESPONSES}

The calculation of the unknown variables is performed in several steps.

1. The so-called trial state is used. Firstly, the change in the total strain is considered only as a change in the elastic strain, which leads to:

$$
\varepsilon_{\text {trial }}^{\mathrm{E}}=\varepsilon_{t}^{\mathrm{E}}+\Delta \varepsilon
$$

where $\varepsilon_{\text {trial }}^{\mathrm{E}}$ is the trial value of the elastic strain; $\varepsilon_{t}^{\mathrm{E}}$ is the elastic strain at the end of the previous time step and $\Delta \varepsilon$ is the change in the total strain in the present time step. Trial values of the other quantities are considered as the values at time $t$. The values of the plasticity and damage functions are calculated using (9) and (10). If the inequalities in the mentioned equations are fulfilled, no plastic or damage quantities are changed and the trial values of strain and stress calculated using (2) are considered as the values in time $t+\Delta t$ and the calculations for the time step are finished. Otherwise the return mapping algorithm described in step 2 is used.

2. Using relations:

$$
\Delta \varepsilon^{\mathrm{P}}=\varepsilon_{\text {trial }}^{\mathrm{E}}-\varepsilon^{\mathrm{E}}
$$

and

$$
\Delta \bar{\varepsilon}^{\mathrm{P}}=\bar{\varepsilon}^{\mathrm{P}}-\bar{\varepsilon}_{\text {trial }}^{\mathrm{P}}
$$

and the fact obvious from relations (13) and (14) that $D$ $=\beta=\lambda^{\mathrm{D}}$, the set of six equations from (9) to (14) can be transformed into the set of two equations with two unknowns $\left(\varepsilon^{\mathrm{E}}\right.$ and $\left.D\right)$.

The first equation has the following form:

$$
\left|E \varepsilon^{\mathrm{E}}\right|-R_{0}-K_{\mathrm{R}}\left(\bar{\varepsilon}^{\mathrm{P}}\right)^{n_{\mathrm{R}}}=0
$$

where $K_{\mathrm{R}}$ and $n_{\mathrm{R}}$ are the shape parameters of the hardening function. The equivalent plastic strain $\bar{\varepsilon}^{\mathrm{P}}$ is calculated as:

$$
\bar{\varepsilon}^{\mathrm{P}}=\bar{\varepsilon}_{\text {trial }}^{\mathrm{P}}+\left(\varepsilon_{\text {trial }}^{\mathrm{P}}-\varepsilon^{\mathrm{E}}\right) \operatorname{sign}\left(E \varepsilon^{\mathrm{E}}\right)
$$

where $\bar{\varepsilon}_{\text {trial }}^{\mathrm{P}}$ is the trial value of the equivalent plastic strain. The term in the shape of the classical power law used in Equations (9) and (18):

$$
\sigma^{y}=R_{0}-K_{\mathrm{R}}\left(\bar{\varepsilon}^{\mathrm{P}}\right)^{n_{\mathrm{R}}}
$$

is the hardening function.

The second equation is:

$$
\frac{1}{2} E\left(\varepsilon^{\mathrm{E}}\right)^{2}-\left(B_{0}+B(D)\right)=0
$$

where term $\left(B_{0}+B(D)\right)$ defines the damage behavior of the material.

Equations (18) and (21) can be solved separately. The first equation (18) needs to be solved numerically. In the present paper, $\varepsilon^{\mathrm{E}}$ is obtained with the golden-section method in the interval $\left\langle\bar{\varepsilon}_{\text {trial }}^{\mathrm{P}}-\Delta \varepsilon, \bar{\varepsilon}_{\text {trial }}^{\mathrm{P}}\right\rangle$. Other variables can be calculated from relations (16) and (19).

The solution of the second equation (21) can be written in the explicit form. It is not necessary to know the exact shape of function $B=B(\beta)=B(D)$ because it is only necessary to define inverse function $B^{-1}=B^{-1}(Y)=$ $B^{-1}\left(\varepsilon^{\mathrm{E}}\right)$. Then

$$
D=B^{-1}\left(\frac{1}{2} E\left(\varepsilon^{\mathrm{E}}\right)^{2}-\frac{1}{2} E\left(\varepsilon_{0}^{\mathrm{E}}\right)^{2}\right)
$$

where $\varepsilon_{0}^{\mathrm{E}}$ is the initial strain for the damage evolution and $B_{0}$ is assumed in the following form:

$$
B_{0}=\frac{1}{2} E\left(\varepsilon_{0}^{\mathrm{E}}\right)^{2}
$$

The exact shape of $D$ is, in this paper, proposed in the following form:

$$
\begin{aligned}
& D=D_{\mathrm{u}}\left\{K_{\mathrm{B}}\left[\frac{\left(\varepsilon^{\mathrm{E}}\right)^{2}-\left(\varepsilon_{0}^{\mathrm{E}}\right)^{2}}{\left(\varepsilon_{\mathrm{f}}^{\mathrm{E}}\right)^{2}}\right]^{n}+\right. \\
& \left.+\left(1-K_{\mathrm{B}}\right)\left[\frac{\left(\varepsilon^{\mathrm{E}}\right)^{2}-\left(\varepsilon_{0}^{\mathrm{E}}\right)^{2}}{\left(\varepsilon_{\mathrm{f}}^{\mathrm{E}}\right)^{2}}\right]^{m}\right\}
\end{aligned}
$$

with

$$
n=\left(\frac{\varepsilon_{\mathrm{r}}}{\varepsilon_{\mathrm{f}}}\right)^{a_{1}}
$$

and

$$
m=\left(\frac{\varepsilon_{\mathrm{f}}}{\varepsilon_{\mathrm{r}}}\right)^{a_{2}}
$$

where $D_{\mathrm{u}}$ is the ultimate damage factor, for which the total failure of the material occurs; $K_{\mathrm{B}}$ and $\varepsilon_{\mathrm{r}}$ are the parameters of the damage-factor dependency defining the position of the inflection point of the damage curve; $\varepsilon_{\mathrm{f}}^{\mathrm{E}}$ is the strain at which failure occurs and $a_{1}$ and $a_{2}$ are the shape parameters.

3. Once the plastic strain, damage factor and all the other variables including the stress are known, the next time step can be solved.

The model includes 11 material parameters summarized in Table 1.

The calculation of the whole analysis of the cyclic tensile test with almost 3000 time steps is done in less than 1 second on the machine with Intel $^{\circledR}$ Core $^{\mathrm{TM}}$ I7-4790, a four-core CPU, running at the frequency of 3.60 GHz using Windows 7 operating system with an SSD disk. 
T. KROUPA et al.: ONE-DIMENSIONAL ELASTO-PLASTIC MATERIAL MODEL WITH DAMAGE ...

Table 1: Material parameters

Tabela 1: Parametri materiala

\begin{tabular}{|c|c|l|}
\hline Parameter & Units & \multicolumn{1}{|c|}{ Meaning } \\
\hline$E$ & $\mathrm{~Pa}$ & Elastic modulus \\
\hline$R_{0}$ & $\mathrm{~Pa}$ & Initial yield stress \\
\hline$K_{\mathrm{r}}$ & $\mathrm{Pa}$ & $\begin{array}{l}\text { Shape parameter of the hardening } \\
\text { curve }\end{array}$ \\
\hline$n_{\mathrm{R}}$ & - & $\begin{array}{l}\text { Shape parameter of the hardening } \\
\text { curve }\end{array}$ \\
\hline$D_{\mathrm{u}}$ & - & $\begin{array}{l}\text { Maximum value of damage that the } \\
\text { material can absorb before failure }\end{array}$ \\
\hline$K_{\mathrm{B}}$ & - & $\begin{array}{l}\text { Coefficient defining the position of } \\
\text { the inflection point }\end{array}$ \\
\hline$\varepsilon_{0}^{\mathrm{E}}$ & - & Initial elastic strain for damage \\
\hline$\varepsilon_{\mathrm{f}}^{\mathrm{E}}$ & - & Strain at which failure occurs \\
\hline$\varepsilon_{\mathrm{r}}^{\mathrm{E}}$ & - & $\begin{array}{l}\text { Strain defining the position of the } \\
\text { inflection point }\end{array}$ \\
\hline$a_{1}$ & - & Shape parameter of damage curve \\
\hline$a_{2}$ & - & Shape parameter of damage curve \\
\hline
\end{tabular}

\section{IDENTIFICATION}

Raw experimental data are pre-processed for the further identification. Important data points such as the maxima and minima of the loading cycles and cross points are found (Figure 3). Averaged values of these points serve as the target for the further identification.

In order to identify the material parameters, the difference between numerical and experimental results is minimized. Function $r$ defining this difference is the so-called total residual. It is the sum of five particular residuals and it is minimized in the identification process.

The first residual is the difference between tensile curves $r_{\mathrm{L}}$ :

$$
r_{\mathrm{L}}=\frac{1}{N_{\mathrm{L}}} \sum_{i=1}^{N_{\mathrm{L}}}\left(\frac{F^{\mathrm{E}}\left(\Delta l_{i}\right)-F^{\mathrm{F}}\left(\Delta l_{i}\right)}{F_{\max }^{\mathrm{E}}}\right)^{2}
$$

where superscripts $\mathrm{E}$ and $\mathrm{N}$ stand for the experimental and numerical analysis, respectively; $N_{\mathrm{L}}$ is the number

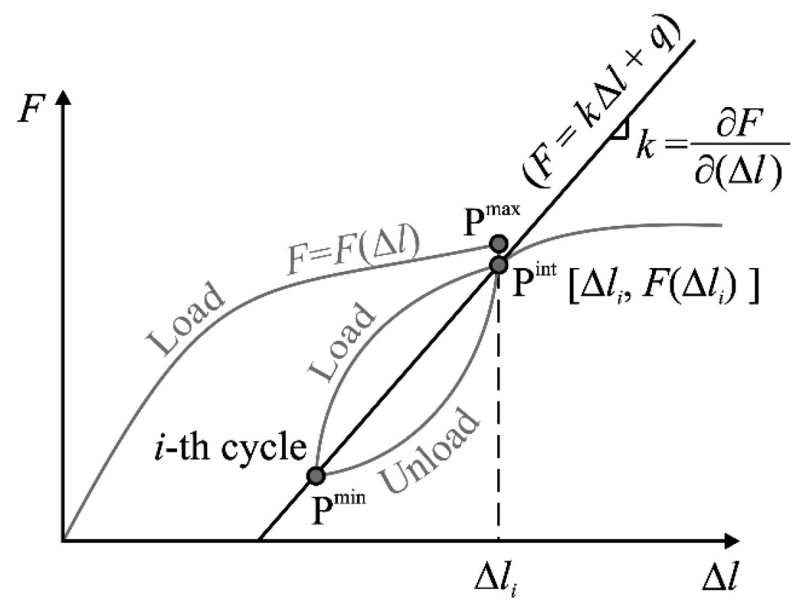

Figure 3: One unload-load cycle and important points

Slika 3: En cikel razbremenjeno - obremenjeno in pomembne točke of points, in which the curves are compared (the number of $P^{\max }$ points); $\Delta l_{i}$ is the elongation of the specimen related to the point $P^{\max }$ and the denominator $F_{\max }^{\mathrm{E}}$ is the maximum force in the target curve used as the weight coefficient.

According to Figure 3, the target for tensile curves in the experiment is considered as the connection of $P^{\max }$ points. Pure epoxy shows a negligible difference between points $P^{\max }$ and $P^{\text {int }}$ unlike the other materials such as textile composites, rubber, etc. In a numerical analysis, if a model does not consider viscoelasticity (which is true of the presented model) these two points coincide. Figure 4 shows the idea of a comparison of the tensile curves and the calculation of residual $r_{\mathrm{L}}$.

The second residual $r_{\mathrm{K}}$ is the difference between the tangents of the unload-load cycles of the experimental data $k^{\mathrm{E}}$ and numerical data $k^{\mathrm{N}}$ :

$$
r_{\mathrm{K}}=\frac{1}{N_{\mathrm{K}}} \sum_{i=1}^{N_{\mathrm{K}}}\left(\frac{k^{\mathrm{E}}\left(\Delta l_{i}\right)-k^{\mathrm{N}}\left(\Delta l_{i}\right)}{k_{\max }^{\mathrm{E}}}\right)^{2}
$$

where $N_{\mathrm{K}}$ is the number of the points, in which the curves are compared; $\Delta l_{i}$ is the elongation of the specimen related to the point $P^{\max }$ and the denominator is the maximum value of the tangent in the experiment used as the weight coefficient. The tangents $k$ are the first derivatives of the straight line connecting points $P^{\max }$ and $P^{\min }$ (Figure 3).

The third residual $r_{\mathrm{mF}}$ is the difference between the values of the maximum forces:

$$
r_{\mathrm{mF}}=\left(1-\frac{F_{\mathrm{max}}^{\mathrm{N}}}{F_{\max }^{\mathrm{E}}}\right)
$$

where $F_{\max }^{\mathrm{N}}$ is the maximum force reached in the numerical analysis and $F_{\max }^{\mathrm{E}}$ is the value from the target function.

The fourth residual $r_{\mathrm{mD}}$ is the difference between the values of the elongations related to the points of maximal forces:

$$
r_{\mathrm{mD}}=\left(1-\frac{\Delta l_{\text {max } F}^{\mathrm{N}}}{\Delta l_{\max F}^{\mathrm{E}}}\right)
$$

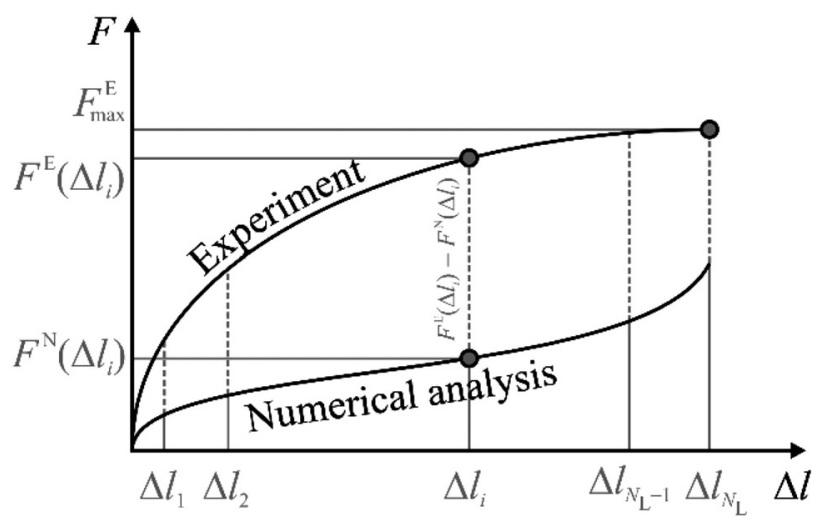

Figure 4: Comparison of the tensile curves

Slika 4: Primerjava nateznih krivulj 
where $\Delta l_{\max F}^{\mathrm{N}}$ and $\Delta l_{\max F}^{\mathrm{E}}$ are the elongations related to the points where force-elongation curves reached their maxima of the force in the numerical analysis and in the experiment.

Finally, the fifth residual $r_{\mathrm{E}}$ is the difference between the values of the force measured after brittle crack (zero values) and the forces calculated in the numerical analysis, subsequent to the point where the curve reaches its maximum:

$$
r_{\mathrm{E}}=\frac{1}{N_{\mathrm{E}}} \sum_{i=1}^{N_{\mathrm{E}}}\left(\frac{F^{\mathrm{N}}\left(\Delta l_{i}\right)}{F_{\max }^{\mathrm{E}}}\right)^{2}
$$

This particular residual is used to induce the model to get to the state where the brittle crack occurs.

Once the particular residuals are known, the total residual can be calculated as:

$$
r=r_{\mathrm{L}}+r_{\mathrm{T}}+r_{\mathrm{mF}}+r_{\mathrm{mD}}+r_{\mathrm{E}}
$$

Optimization software OptiSLang 3.2.3. was used. Gradient and simple design improvement algorithms were used. ${ }^{8}$

\section{RESULTS}

Figure 5 shows the force-elongation dependency. Note that the deviation of the maximum forces in the experiments is not negligible.

Considering the deviation of the experimental results, the identified dependency shows sufficient agreement; nevertheless, it is slightly more curved than the experimental target.

Figure 6 shows the comparison of the results for the calculated tangents of the unload-load cycles. The first cycle was ignored because of the influence of the inaccuracies of the experimental results for low loading

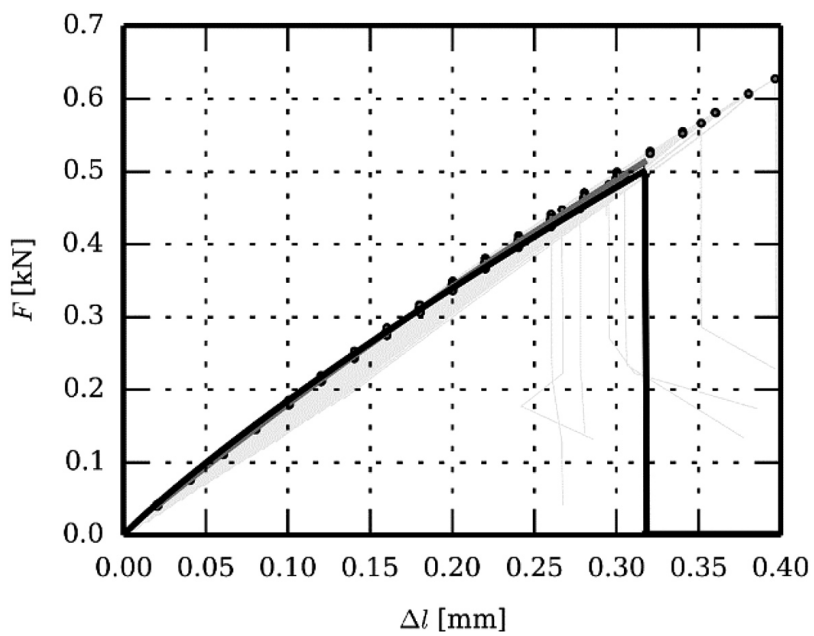

Figure 5: Force-elongation dependency. Dots represent points $P^{\max }$ Grey bold line is the target experiment; black bold line is the numerical analysis.

Slika 5: Odvisnost sile od raztezka. Točke predstavljajo $P^{\max }$. Siva, ojačana linija je cilj preizkusa, črna ojačana linija je numerična analiza.

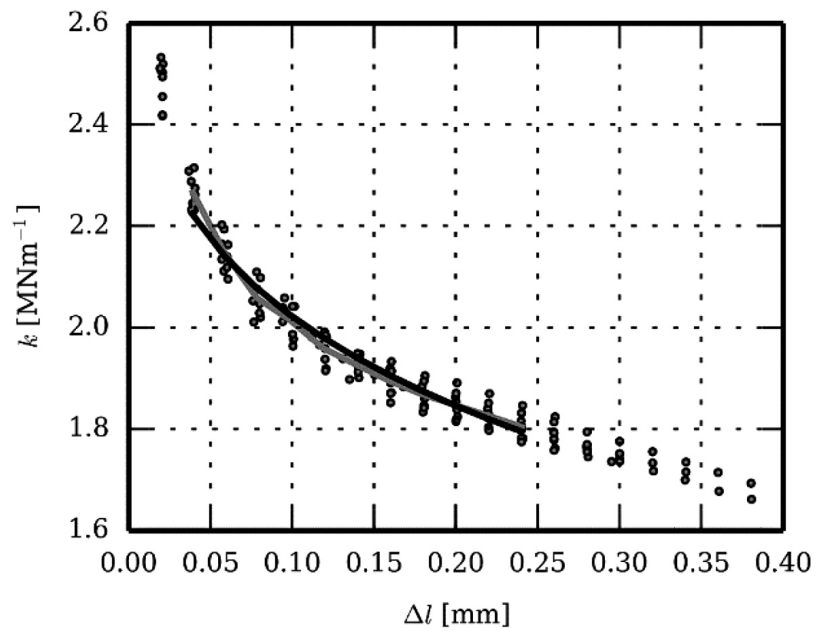

Figure 6: Tangent of unload-load cycle vs. elongation. Grey bold line is the target experiment; black bold line is the numerical analysis. Dots represent tangents $k$ for each cycle in each experiment.

Slika 6: Tangenta na cikel obremenjeno - razbremenjeno, raztezek. Siva ojačana krivulja je cilj raziskave, črna debela krivulja je nume-

forces. The comparison of the curves is performed within the interval where all the measured specimens provide the necessary data. The first specimen reached its strength limit at an elongation of about $0.25 \mathrm{~mm}$. The justification for this choice is as follows: after reaching the mentioned elongation limit, significant jumps in the dependence of the averaged experimental results occur because of the disappearing data from each cracked specimen.

Figure 7 shows the identified hardening function.

Dependency of the damage factor on the elastic strain is shown in Figure 8. The modulus $E_{\mathrm{D}}=E(1-D)$ occurs right before the brittle fracture and equals $3.55 \mathrm{GPa}$ and the damage factor is $D=0.47$ (see the gray circle in Figure 8).

The identified material parameters including those calculated directly from the experiment are given in Table 2.

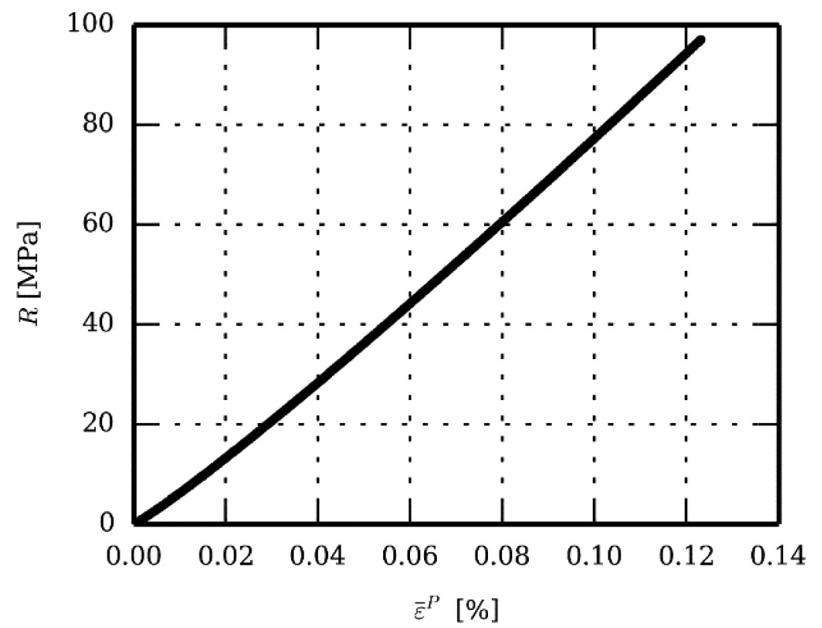

Figure 7: Hardening function

Slika 7: Funkcija utrjevanja 
T. KROUPA et al.: ONE-DIMENSIONAL ELASTO-PLASTIC MATERIAL MODEL WITH DAMAGE ...

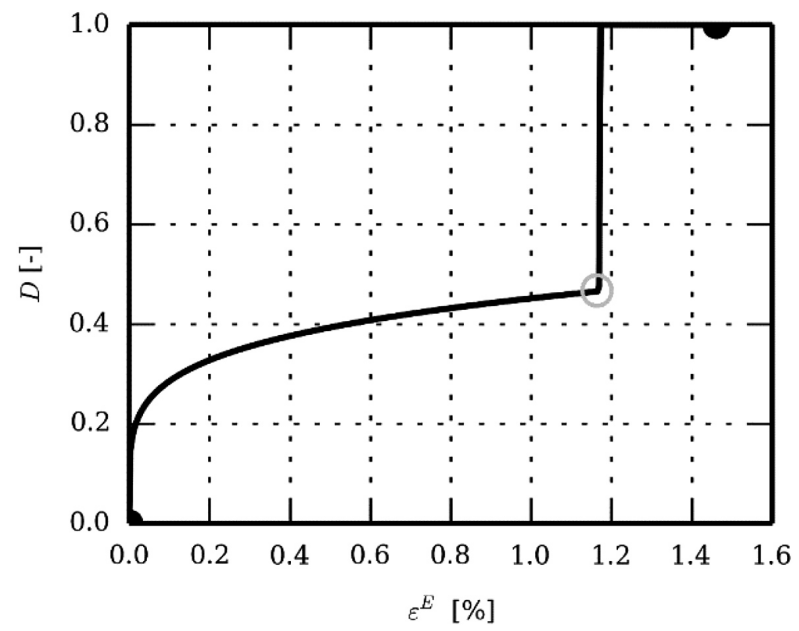

Figure 8: Damage function. Grey circle shows the initiation of brittle fracture and the final failure of the material.

Slika 8: Funkcija poškodb. Sivi krogi kažejo pričetke krhkega loma in končno porušitev materiala

Table 2: Identified parameters. Parameters with * were calculated directly from the experimental results.

Tabela 2: Ugotovljeni parametric. Parametri označeni z *, so bili izračunani neposredno iz eksperimentalnih rezultatov

\begin{tabular}{|c|c|c|}
\hline Parameter & Value & Unit \\
\hline$E$ & 6.64 & $\mathrm{GPa}$ \\
\hline$R_{0}$ & 0.00 & $\mathrm{MPa}$ \\
\hline$K_{\mathrm{R}}$ & 149.19 & $\mathrm{GPa}$ \\
\hline$n_{\mathrm{R}}$ & 1.10 & - \\
\hline$D_{\mathrm{u}}$ & 0.76 & - \\
\hline$K_{\mathrm{B}}$ & 0.62 & - \\
\hline$\varepsilon_{0}^{\mathrm{E}}$ & 0.00 & $\%$ \\
\hline$\varepsilon_{\mathrm{r}}^{\mathrm{E}}$ & 0.46 & $\%$ \\
\hline$\varepsilon_{\mathrm{f}}^{\mathrm{E}}$ & 1.17 & $\%$ \\
\hline$a_{1}$ & 2.48 & - \\
\hline$a_{2}$ & 6.95 & - \\
\hline$v^{*}$ & 0.29 & $\mathrm{MPa}$ \\
\hline$\sigma_{\mathrm{S}}^{*}$ & 41.67 & \\
\hline
\end{tabular}

\section{CONCLUSION}

A relatively simple and effective algorithm for the calculation of the response of a material, showing elastic, plastic and damage behavior is proposed. The plastic and damage-flow problems are solved separately. A set of equations is transformed into a single nonlinear equation in the case of the plastic-flow problem and the equation is solved with the golden-section algorithm, which is extremely effective. The other set of equations that need to be solved in order to calculate the damage factor is transformed into one explicit formula for calculating the damage factor.

An appropriate identification process is proposed and its effectivity is shown in the case of the cyclic tensile tests of pure epoxy resin. The function that is minimized during the identification process is the sum of five independent residuals, each quantifying a difference between experimental and numerical results. These residuals express the differences between tensile-elongation dependencies and the values of the tangents of the unload-load cycles, the distance between the point of the maximum force reached in force and elongation directions and the value of the force after the brittle fracture of the specimen is minimized. The model and the identification process are robust and time effective.

\section{Acknowledgement}

This publication was supported by project LO1506 of the Czech Ministry of Education, Youth and Sports.

\section{REFERENCES}

${ }^{1}$ T. Kroupa, V. Laš, R. Zemčík: Improved nonlinear stress-strain relation for carbon-epoxy composites and identification of material parameters, Journal of Composite Materials, 45 (2011) 9, 1045-1057, doi:10.1177/0021998310380285

${ }^{2}$ R. Zemčík, R. Kottner, V. Laš, T. Plundrich, Identification of material properties of quasi-unidirectional carbon-epoxy composite using modal analysis, Mater. Tehnol., 43 (2009) 5, 257-260

${ }^{3}$ S. Ogihara, K. L. Reifsnider: Characterization of Nonlinear Behavior in Woven Composite Laminates, Applied Composite Materials, 9 (2001), 249-263, doi:10.1023/A:1016069220255

${ }^{4}$ S. Murakami, Continuum damage mechanics, A continuum mechanics approach to the analysis of damage and fracture, Springer, 2012

${ }^{5}$ E. A. de Souza Neto, D. Perić, D. R. J. Owen, Computational Methods for Plasticity: Theory and Applications, Wiley, 2008

${ }^{6}$ V. Laš, R. Zemčík, Progressive Damage of Unidirectional Composite Panels, Journal of Composite Materials, 42 (2008) 1, 25-44, doi:10.1177/0021998307086187

${ }^{7}$ K. J. Bathe, Finite element procedures, Prentice Hall, Upper Saddle River, New Jersey 07458, USA, 2007

${ }^{8}$ J. S. Arora, Introduction to Optimum Design, Elsevier, 2004 